\title{
EFEKTIFITAS BIJI KELOR (Moringa oleifera), BIJI SALAK (Salacca zalacca), DAN BIJI PEPAYA (Carica papaya) SEBAGAI BAHAN KOAGULAN DALAM MENURUNKAN KEKERUHAN AIR
}

\author{
Intan Permata, Margono, Ngadino
}

\begin{abstract}
Water purification is typically carried out using chemical coagulants like Tawas, local name for Aluminum sulfate. In many parts of the world experts are looking into coagulant materials derived from plants. Among many of them is the Moringa seeds. Moringa seeds contain water-soluble proteins, when crushed and dissolved in water it will form a positively charged solution. Electrophoreses Test proved that positively charged solution were also resulted from the use of Salak seeds and Papaya seed. The purpose of this study was to analyze the differences in coagulation using Moringa (Moringa oleifera), Salak (Salacca zalacca), and Papaya seeds (Carica Papaya).

The study was performed in a quasi-experimental set up exercising a pretest-posttest design. The object for the study was water sample taken from a river used by the community in kecamatan Krembung for their water source. As much as $1000 \mathrm{ml}$ of river water was used in each test run. Test containers were treated with natural coagulants. Coagulant materials used in the tests were Tawas powder, Moringa, Salak, and Papaya seeds at a dose-series of $50 \mathrm{ppm}$ to $1000 \mathrm{ppm}$. The resulted data were analyzed using Kruskal - Wallis Test.

There was a significant difference with regard to optimal dose of the natural coagulants as well as the percentage of turbidity reduction. The optimal dose for Moringa seeds was 130 ppm with a percentage of reduction at $97,3 \%$ that reduced turbidity down to 2.7 NTU. The optimal dose for Salak seeds was $100 \mathrm{ppm}$ that resulted in a percentage reduction of $89,2 \%$ and reduced the turbidity down to 10.9 NTU. The optimal dose for Papaya seeds was $50 \mathrm{ppm}$ with a percentage of decline at $83,4 \%$ reducing the turbidity down to 16,7 NTU. Moringa seeds coagulant has maximum turbidity reducing capability, while the other two natural coagulants, Salak and Papaya seeds, were not in their maximum levels of turbidity reducing capabilities.

At a dose of $200 \mathrm{ppm}$ Moringa seeds exhibited a greater ability as a coagulant in lowering water turbidity compared to the other natural coagulants, Salak seeds at a dose of $100 \mathrm{ppm}$ and Papaya seeds at a dose of $50 \mathrm{ppm}$. The study concluded that Moringa seeds can be applied as a substitute for chemical coagulants provided they are used within $1 \times 24$ hours.

Key Words : Turbidity and Coagulant
\end{abstract}

\section{PENDAHULUAN Latar Belakang}

Air sangat besar pengaruhnya terhadap kehidupan. Air adalah bagian dari lingkungan fisis yang sangat esensil tidak hanya dalam proses - proses hidup, tetapi juga untuk proses - proses lainnya, seperti untuk industri, pertanian, pemadam kebakaran, dan lain - lain. (Sanropie dkk, 1984). Akan tetapi kualitas air bersih sekarang ini sudah semakin menurun. Selain itu, air juga bisa menimbulkan masalah, seperti masalah banjir dan masalah-masalah kesehatan.

Menurut Keputusan Menteri Kesehatan Republik Indonesia Nomor 492 Tahun 2010, dalam rangka meningkatkan derajat kesehatan masyarakat, perlu dilakukan berbagai upaya termasuk pengawasan kualitas air minum yang dikonsumsi masyarakat.

Salah satu persyaratan kesehatan air minum adalah dengan melakukan pengolahan air. Dalam instalasi pengolahan air, penjernihan dilakukan menggunakan bahan koagulan kimiawi, seperti Alumunium Sulfat dan garam besi yang dapat merubah bentuk cair menjadi semi - padat.

Selanjutnya diteruskan dengan flokulasi, yaitu pengadukan secara perlahan sehingga partikel berukuran kecil teragregasi menjadi partikel yang berukuran lebih besar. Dengan demikian akan lebih mudah menghilangkan flok 
tersebut dengan cara pengendapan atau penyaringan. (Margono, 2010).

Saat ini berkembang bahan koagulan yang berasal dari tumbuh - tumbuhan. Salah satu contohnya Biji Kelor yang mampu menurunkan kekeruhan air dan kandungan berbahaya yang ada di dalamnya.

Biji Kelor (Moringa oleifera) berisi protein larut air yang jika dilarutkan akan membentuk larutan bermuatan positif. Protein tersebut berlaku seperti halnya koagulan polimer yang bermuatan positif. Jika dibubuhkan ke dalam air maka protein akan berikatan dengan partikel - partikel yang kebanyakan bermuatan negatif dan menyebabkan kekeruhan air. (Margono, 2010).

Berdasarkan uji muatan larutan, protein larut air juga terdapat pada Biji Salak dan Biji Pepaya. Di mana telah dibuktikan saat dilakukan Uji Elektroforesis, larutan Biji Salak dan larutan Biji Pepaya juga memiliki protein larut air yang dibuktikan dengan adanya koloid yang bermuatan positif bergerak menuju elektrode bermuatan negatif.

\section{Tujuan Penelitian}

Mengetahui perbedaan bahan koagulan menggunakan Biji Kelor (Moringa oleifera), Biji Salak (Salacca zalacca), dan Biji Pepaya (Carica papaya) dalam menurunkan kekeruhan air.

\section{METODE PENELITIAN}

\section{Jenis Penelitian}

Jenis penelitian ini adalah eksperimen kuasi. Penelitian ini bersifat sebagai penelitian laboratorium. Rancangan penelitian ini menggunakan rancangan "Pre-Post Test Design".

\section{Lokasi dan Waktu Penelitian}

Lokasi yang dijadikan tempat penelitian adalah Laboratorium Kimia Lingkungan Kesehatan Lingkungan Surabaya. Penelitian ini dilakukan pada bulan Mei 2013.

\section{Objek Penelitian}

Objek penelitian yang digunakan adalah air sungai yang digunakan oleh masyarakat di sekitar wilayah Kecamatan Krembung. Dalam penelitian ini jumlah sampel air sungai adalah $1000 \mathrm{ml}$ pada setiap uji. Di mana untuk setiap uji terdapat perlakuan dengan menggunakan bahan koagulan alami yang meliputi uji perlakuan serbuk Biji Kelor, Biji Salak, dan Biji Pepaya.

\section{Variabel Penelitian}

Variabel bebas dalam penelitian ini adalah Dosis (mg/L atau $\mathrm{ppm}$ ) serbuk Biji Kelor, Biji Salak, dan Biji Pepaya. Variabel terikat dalam penelitian ini adalah Hasil pengolahan yaitu tingkat kekeruhan air (NTU) dan persentasi penurunan (\%) yaitu selisih antara tingkat kekeruhan awal dan tingkat kekeruhan akhir. Dan Variabel pengganggu dalam penelitian ini adalah $\mathrm{pH}$ atau derajat keasaman.

\section{Metode Analisis Data}

Data tingkat kekeruhan akhir setelah diberikan dosis koagulan alami sebagai larutan koagulan yang diinjeksikan pada air baku serta persentasi penurunan antara kekeruhan awal dan kekeruhan akhir akan disajikan dalam bentuk tabel dan grafik yang selanjutnya dianalisis menggunakan Uji Kruskal Wallis. 


\section{HASIL PENELITIAN}

Perlakuan dengan Jar Test menggunakan bahan koagulan dengan berbagai macam dosis. Pengamatan dilakukan dengan mengamati flok yang terbentuk dari ikatan masing masing koagulan.

TABEL 1.

DOSIS OPTIMAL KOAGULAN DAN PERSENTASI PENURUNAN KOAGULAN ALAMI DALAM MENURUNKAN KEKERUHAN AIR SAMPAI MENCAPAI KEKERUHAN TERENDAH

\begin{tabular}{|c|c|c|c|c|c|c|c|c|}
\hline \multirow[t]{2}{*}{ No } & \multirow{2}{*}{$\begin{array}{l}\text { Dosis } \\
\text { Bahan } \\
\text { Koagulan } \\
\text { (ppm) }\end{array}$} & \multirow{2}{*}{$\begin{array}{l}\text { Tingkat } \\
\text { Kekeruhan } \\
\text { Air Awal } \\
\text { (NTU) }\end{array}$} & \multicolumn{2}{|c|}{ Biji Kelor } & \multicolumn{2}{|c|}{ Biji Salak } & \multicolumn{2}{|c|}{ Biji Pepaya } \\
\hline & & & $\begin{array}{l}\text { Tingkat } \\
\text { Kekeruhan } \\
\text { Air Akhir } \\
\text { (NTU) }\end{array}$ & $\begin{array}{c}\text { Persentasi } \\
\text { Penurunan } \\
(\%)\end{array}$ & $\begin{array}{l}\text { Tingkat } \\
\text { Kekeruhan } \\
\text { Air Akhir } \\
\text { (NTU) }\end{array}$ & $\begin{array}{c}\text { Persentasi } \\
\text { Penurunan } \\
(\%)\end{array}$ & $\begin{array}{l}\text { Tingkat } \\
\text { Kekeruhan } \\
\text { Air Akhir } \\
\text { (NTU) }\end{array}$ & $\begin{array}{c}\text { Persentasi } \\
\text { Penurunan } \\
(\%)\end{array}$ \\
\hline 1. & 50 & 100,4 & 5,7 & 94,3 & 12,3 & 87,7 & 16,7 & 83,4 \\
\hline 2. & 80 & 101,8 & 5,6 & 94,5 & 13,1 & 87,1 & 23,4 & 77,0 \\
\hline 3. & 100 & 101,1 & 5,4 & 94,7 & 10,9 & 89,2 & 16,9 & 83,3 \\
\hline 4. & 130 & 100,6 & 2,7 & 97,3 & 13,9 & 86,2 & 29,0 & 71,2 \\
\hline 5. & 150 & 101,7 & 2,4 & 97,6 & 14,6 & 85,6 & 23,7 & 76,7 \\
\hline 6. & 180 & 104,2 & 2,3 & 97,8 & 14,9 & 85,7 & 25,5 & 75,5 \\
\hline 7. & 200 & 103,5 & 1,7 & 98,4 & 13,7 & 86,8 & 26,4 & 74,5 \\
\hline 8. & 250 & 101,7 & 4,7 & 95,4 & 13,6 & 86,6 & 31,3 & 69,2 \\
\hline 9. & 300 & 100,5 & 7,2 & 92,8 & 15,7 & 84,4 & 42,1 & 58,1 \\
\hline 10. & 400 & 99,8 & 10,5 & 89,5 & 22,6 & 77,4 & 49,9 & 50,0 \\
\hline 11. & 500 & 99,9 & 15,1 & 84,9 & 34,5 & 65,5 & 54,0 & 45,9 \\
\hline 12. & 600 & 99,9 & 14,4 & 85,6 & 55,9 & 44,0 & 51,9 & 48,0 \\
\hline 13. & 750 & 99,4 & 14,2 & 85,7 & 60,9 & 38,7 & 62,9 & 36,7 \\
\hline 14. & 900 & 99,7 & 4,6 & 95,4 & 60,1 & 39,7 & 85,1 & 14,6 \\
\hline 15. & 1000 & 99,7 & 5,2 & 94,8 & 59,0 & 40,8 & 86,1 & 13,6 \\
\hline
\end{tabular}

TABEL 2.

UJI KRUSKAL WALLIS TINGKAT KEKERUHAN AKHIR MENGGUNAKAN DOSIS KOAGULAN ALAMI

\begin{tabular}{|c|c|c|c|c|c|c|}
\hline No & $\begin{array}{c}\text { Dosis Bahan } \\
\text { Koagulan } \\
\text { (ppm) }\end{array}$ & $\begin{array}{c}\text { Tingkat } \\
\text { Kekeruhan Air } \\
\text { Awal (NTU) }\end{array}$ & $\begin{array}{c}\text { Tingkat } \\
\text { Kekeruhan Air } \\
\text { Akhir } \\
\text { Menggunakan } \\
\text { Biji Kelor } \\
\text { (NTU) }\end{array}$ & $\begin{array}{c}\text { Tingkat } \\
\text { Kekeruhan Air } \\
\text { Akhir } \\
\text { Menggunakan } \\
\text { Biji Salak } \\
\text { (NTU) }\end{array}$ & $\begin{array}{c}\text { Tingkat } \\
\text { Kekeruhan Air } \\
\text { Akhir } \\
\text { Menggunakan } \\
\text { Biji Pepaya } \\
\text { (NTU) }\end{array}$ & $\begin{array}{c}\text { (N) } \\
\text { Sig) }\end{array}$ \\
\hline 1. & 50 & 100,4 & 5,7 & 13,1 & 23,4 \\
\hline 2. & 80 & 101,8 & 5,6 & 10,9 & 16,9 \\
\hline 3. & 100 & 101,1 & 5,4 & 13,9 & 29,0 \\
\hline 4. & 130 & 100,6 & 2,7 & 14,6 & 23,7 \\
\hline 5. & 150 & 101,7 & 2,4 & 14,9 & 25,5 \\
\hline 6. & 180 & 104,2 & 2,3 & 13,7 & 26,4 \\
\hline 7. & 200 & 103,5 & 1,7 & 13,6 & 31,3 \\
\hline 8. & 250 & 101,7 & 4,7 & 15,7 & 42,1 \\
\hline 9. & 300 & 100,5 & 7,2 & 22,6 & 49,9 \\
\hline 10. & 400 & 99,8 & 10,5 & 34,5 & 54,0 \\
\hline 11. & 500 & 99,9 & 15,1 & 55,9 & 51,9 \\
\hline 12. & 600 & 99,9 & 14,4 & 60,9 & 62,9 \\
\hline 13. & 750 & 99,4 & 14,2 & 60,1 & 85,1 \\
\hline 14. & 900 & 99,7 & 4,6 & 59,0 & 86,1 \\
\hline 15. & 1000 & 99,7 & 5,2 & & \\
\hline
\end{tabular}

Hasil uji hipotesis yaitu :

HO : Rata - rata kekeruhan menggunakan bahan koagulan diantara Biji Kelor, Biji Salak, dan Biji Pepaya adalah SAMA

H1 : Ada perbedaan rata - rata kekeruhan menggunakan bahan koagulan diantara Biji Kelor, Biji Salak, dan Biji Pepaya

Daerah tolak $\mathrm{HO}$ apabila nilai $\mathrm{P}<\mathrm{a}$. 
Berdasarkan hasil tabel.2 di atas nilai P lebih kecil dari a yaitu 0,001, maka H0 ditolak. Jadi kesimpulannya ada perbedaan antara rata - rata kekeruhan menggunakan bahan koagulan diantara Biji Kelor, bahan koagulan Biji Salak, dan bahan koagulan Biji Pepaya.

TABEL 3.

UJI KRUSKAL WALLIS UNTUK PERSENTASI PENURUNAN ANTARA TINGKAT KEKERUHAN AWAL DENGAN TINGKAT KEKERUHAN AKHIR MENGGUNAKAN KOAGULAN ALAMI

\begin{tabular}{|c|c|c|c|c|c|}
\hline No & $\begin{array}{c}\text { Dosis Bahan } \\
\text { Koagulan } \\
\text { (ppm) }\end{array}$ & $\begin{array}{c}\text { Persentasi } \\
\text { Penurunan } \\
\text { Menggunakan } \\
\text { Biji Kelor } \\
(\text { NTU) }\end{array}$ & $\begin{array}{c}\text { Persentasi } \\
\text { Penurunan } \\
\text { Menggunakan } \\
\text { Biji Salak } \\
\text { (NTU) }\end{array}$ & $\begin{array}{c}\text { Persentasi } \\
\text { Penurunan } \\
\text { Menggunakan } \\
\text { Biji Pepaya } \\
\text { (NTU) }\end{array}$ & $\begin{array}{c}\text { Nilai P } \\
\text { (Asymp Sig) }\end{array}$ \\
\hline 1. & 50 & 94,3 & 87,7 & 83,4 & \multirow{2}{*}{0,001} \\
\hline 2. & 80 & 94,5 & 87,1 & 77,0 & \\
\hline 3. & 100 & 94,7 & 89,2 & 83,3 \\
\hline 4. & 130 & 97,3 & 86,2 & 71,2 \\
\hline 5. & 150 & 97,6 & 85,6 & 76,7 \\
\hline 6. & 180 & 97,8 & 85,7 & 75,5 \\
\hline 7. & 200 & 98,4 & 86,8 & 74,5 \\
\hline 8. & 250 & 95,4 & 86,6 & 69,2 \\
\hline 9. & 300 & 92,8 & 84,4 & 58,1 \\
\hline 10. & 400 & 89,5 & 77,4 & 50,0 \\
\hline 11. & 500 & 84,9 & 65,5 & 45,9 \\
\hline 12. & 600 & 85,6 & 44,0 & 48,0 \\
\hline 13. & 750 & 85,7 & 38,7 & 36,7 \\
\hline 14. & 900 & 95,4 & 39,7 & 14,7 \\
\hline 15. & 1000 & 94,8 & 40,8 & 13,6 \\
\end{tabular}

Hasil hipotesa yaitu :

HO : Rata - rata persentasi penurunan menggunakan bahan koagulan diantara Biji Kelor, Biji Salak, dan Biji Pepaya adalah SAMA

$\mathrm{H} 1$ : Ada perbedaan rata - rata persentasi penurunan menggunakan bahan koagulan diantara Biji Kelor, Biji Salak, dan Biji Pepaya

Daerah tolak $\mathrm{HO}$ apabila nilai $\mathrm{P}<\mathrm{a}$.

Berdasarkan hasil tabel 3. di atas nilai $P$ lebih kecil dari a yaitu 0,001 , maka $\mathrm{HO}$ ditolak. Jadi kesimpulannya ada perbedaan antara rata - rata persentasi penurunan menggunakan bahan koagulan diantara Biji Kelor, bahan koagulan Biji Salak, dan bahan koagulan Biji Pepaya.

$\mathrm{pH}$ suatu larutan sangat berpengaruh terhadap jalannya proses koagulasi flokulasi. $\mathrm{pH}$ optimum suatu larutan yaitu antara 5 - 8. $\mathrm{pH}$ awal air baku yaitu 7. $\mathrm{pH}$ akhir air baku setelah diinjeksikan dengan larutan koagulan Biji Kelor, Biji Salak, dan Biji Pepaya berturut - turut sebesar 7, 8, dan 7.

Biji Kelor memberikan efek negatif yaitu bau yang menyengat. Biji Pepaya memberikan efek warna yang paling keruh. Semua larutan koagulan tidak memberikan efek rasa. Semua larutan koagulan dari bahan koagulan Biji Kelor, Biji Salak, dan Biji Pepaya bersifat mengadsorbsi koloid sehingga terbentuk endapan setelah pengadukan lambat.
Dengan demikian Biji Kelor, Biji Salak, dan Biji Pepaya bersifat sebagai Koagulan.

\section{PEMBAHASAN}

Perbedaan dosis koagulan dan persentasi penurunan koagulan akan mempengaruhi proses koagulasi dan flokulasi yang mempengaruhi kualitas dari masing - masing koagulan alami yang diujikan. Adapun perbedaan dosis koagulan dan persentasi penurunan koagulan alami dalam menurunkan kekeruhan air yaitu sebagai berikut :

\section{Biji Kelor}

Dosis optimal Biji Kelor yaitu 130 ppm. Sedangkan persentasi penurunannya sebesar 97,3\% mampu menurunkan kekeruhan mencapai 2,7 NTU. Pada dosis 200 ppm, memang mampu menurunkan kekeruhan mencapai 1,7 NTU, akan tetapi dengan pertimbangan efek maka dosis 130 
ppm lebih efektif karena sudah menurunkan kekeruhan dibawah 5 NTU.

\section{Biji Salak}

Dosis optimal Biji Salak yaitu 100 ppm. Sedangkan persentasi penurunannya sebesar $89,2 \%$ mampu menurunkan kekeruhan mencapai 10,9 NTU.

\section{Biji Pepaya}

Dosis optimal Biji Pepaya yaitu 50 ppm. Sedangkan persentasi penurunannya sebesar 83,4\% mampu menurunkan kekeruhan mencapai 16,7 NTU. Melihat trend daripada grafik pembubuhan dosis pepaya, dimungkinkan kekeruhan dapat diturunkan dengan dosis dibawah 50 ppm. Dengan demikian dapat dilakukan penelitian lanjutan untuk bahan koagulan dengan Biji Pepaya untuk dosis dibawah 50 ppm.

Apabila dilihat berdasarkan dosis optimal yang diberikan, maka bahan koagulan alami yang paling baik dalam menurunkan kekeruhan air yaitu Biji Pepaya karena hanya membutuhkan dosis 50 ppm untuk menurunkan kekeruhan air. Bahkan mungkin bisa diturunkan lagi dosisnya. Akan tetapi tingkat kekeruhan airnya belum mencapai baku mutu karena hanya menurunkan sampai 16,7 NTU.

Oleh karena itu, berdasarkan analisa statistik menggunakan Uji Kruskal Wallis menjawab Hipotesa Penelitian bahwa "Ada perbedaan bahan koagulan diantara Biji Kelor (Moringa oleifera), Biji Salak (Salacca zalacca), dan Biji Pepaya (Carica papaya)".

Jenis bahan koagulan alami yang paling baik adalah Biji Kelor karena mampu menurunkan kekeruhan mencapai 2,7 NTU dengan persentasi penurunannya sebesar $97,3 \%$.

\section{Kendala - Kendala dalam Penelitian 1. Memperoleh Bahan Alami}

Biji Kelor agak sulit diperoleh pada musim - musim tertentu apalagi yang masak atau sudah tua di pohon. Selain itu Biji Kelor juga tidak dapat bertahan dalam waktu yang lama. Karena biji salak dan biji pepaya mudah ditemui dan dimanfaatkan, penggunaannya pun tetap harus disesuaikan dengan kebutuhan.

\section{Kekeruhan Awal}

Tingkat kekeruhan awal sangat berpengaruh pada perhitungan persentasi penurunan dalam menentukan dosis optimal. Oleh karena itu, kekeruhan awal harus dipehatikan.

\section{Kemampuan Koagulan Alami Belum Maksimal}

Kemampuan Biji Salak dan Biji Pepaya yang belum maksimal bisa disebabkan oleh larutan koagulan itu sendiri yang menimbulkan efek kekeruhan. Namun hendaknya diingat bahwa melalui Uji Elektroforesis larutan biji salak dan biji pepaya memiliki muatan positif.

Faktor lain mungkin terjadi karena proses penyiapan bahan menjadi serbuk, terjadinya kontak dengan udara / teroksidasi dalam waktu penyimpanan diduga menyebabkan penurunan daya ikat yang dimiliki oleh bahan, ukuran serbuk yang berbeda-beda, dan kadar air dalam setiap jenis serbuk yang belum terukur, semuanya diduga ikut mempengaruhi proses koagulasi - flokulasi.

\section{Lama Waktu Pembentukan Flok}

Lama waktu yang dibutuhkan larutan koagulan dalam mengikat flok tidak diteliti secara detail. Penyebabnya ialah fokus terhadap penentuan dosis optimal dan jangka waktu yang tersedia untuk kegiatan penelitian.

\section{Hasil Uji Organoleptik}

Pengukuran kualitas fisik menjadi perhatian karena koagulan digunakan berasal dari bahan alami. Efek paling mencolok yaitu timbulnya bau menyengat dari larutan yang berasal dari Biji Kelor. Cara mencegah paling sederhana yaitu dengan segera menggunakan air yang telah dijernihkan tidak lebih dari 24 jam. Larutan koagulan biji salak dan biji pepaya memberikan warna yang kurang jernih karena masih belum mampu mencapai kekeruhan sebesar 5 NTU.

Semua larutan koagulan alami bersifat mengadsorbsi koloid sehingga terbentuk endapan setelah pengadukan lambat. Dengan demikian Biji Kelor, Biji Salak, dan Biji Pepaya sebagai bahan koagulan mampu menurunkan kekeruhan air.

\section{KESIMPULAN}

1. Biji Kelor, Biji Salak, dan Biji Pepaya memiliki sifat sebagai koagulan karena mampu mengadsorbsi partikel koloid 
sehingga membentuk flok dan membentuk endapan setelah pengadukan lambat.

2. Dosis optimal Biji Kelor sebesar 130 $\mathrm{ppm}$ dengan persentasi penurunannya sebesar $97,3 \%$ menurunkan kekeruhan mencapai 2,7 NTU. Dosis optimal Biji Salak sebesar $100 \mathrm{ppm}$ dengan persentasi penurunannya sebesar $89,2 \%$ menurunkan kekeruhan mencapai 10,9 NTU. Dosis optimal Biji Pepaya sebesar 50 ppm dengan persentasi penurunannya sebesar $83,4 \%$ menurunkan kekeruhan mencapai 16,7 NTU.

3. Bahan koagulan alami yang paling baik adalah Biji Kelor.

\section{SARAN}

1. Biji Kelor, Biji Salak, dan Biji Pepaya dapat dimanfaatkan sebagai koagulan alami.

2. Untuk situasi pedesaan, Biji Kelor, Biji Salak, dan Biji Pepaya dapat dipakai sebagai pengganti Tawas yang lebih aman dan mudah ditemukan di sekitar.

3. Perlu dilakukan penelitian lebih lanjut terkait bahan alami Biji Kelor, Biji Salak, dan Biji Pepaya seperti :

a. Upaya meminimalisir bau.

b. Upaya penggunaan Biji Salak dan Biji Pepaya agar mampu menurunkan kekeruhan hingga mencapai 5 NTU.

c. Pemberian dosis dibawah $50 \mathrm{ppm}$ untuk bahan koagulan dari Biji Pepaya.

d. Uji lama waktu dalam mengikat flok pertama setelah dilakukan pengadukan lambat.

e. Meningkatkan efektifitas Biji Kelor, Biji Salak, dan Biji Pepaya sebagai koagulan dengan terlebih dahulu mengayak serbuknya menggunakan Mesh ukuran 80.

f. Terlebih dahulu menghitung persentasi penyusutan kadar air untuk masing - masing jenis biji. g. Upaya melakukan dehidrasi biji selain dengan menggunakan sinar matahari.

h. Memudahkan pemanfaatan Biji Kelor, Biji Salak, dan Biji Pepaya oleh masyarakat, dalam konteks peningkatan budidaya dan pelestarian lingkungan.

\section{DAFTAR PUSTAKA}

Airlanggiwati, dkk. 2011. Inventasi Beberapa Indikator Tujuan Pembangunan Milenium (MDGs) di Jawa Timur. Surabaya : UPN PRESS.

Alaerts, dan Santika, Sri Simestri. 1984. Metoda Penelitian Air. Surabaya : Usaha Nasional.

Keputusan Menteri Kesehatan Republik Indonesia Nomor 492 Tahun 2010 Tentang Persyaratan Kualitas Air Minum

Margono. 2010. Buku Saku Pekerja Lapangan. Surabaya : Jurusan Kesehatan Lingkungan Surabaya.

Margono. 2010. Penyediaan Air Bersih Buku Ajar Jilid 1. Surabaya : Jurusan Kesehatan Lingkungan Surabaya..

Notoadmodjo, Soekidjo. 2010. Metodologi Penelitian Kesehatan. Jakarta : PT. Rineka Cipta.

Pikir, Suharno. 1989. Kimia Dasar. Surabaya : Airlangga University Press.

Sanropie, Djasio. 1984. Penyediaan Air Bersih. Jakarta : Departemen Kesehatan

Sudjarwo, dkk. 2007. Buku Ajar Panduan Praktikum Mata Kuliah PAPLC - A. Surabaya : Jurusan Kesehatan Lingkungan Surabaya.

Tietze, Harald W. 2002. Terapi Pepaya. Jakarta : Prestasi Pustaka Publisher.

Wardojo. 2003. Kimia Lingkungan. Surabaya : Jurusan Kesehatan Lingkungan Surabaya. 